\title{
Internet as an Effective Source of Health Information and Intervention in Several Countries: A Systematic Review
}

\section{Anggia Ratri Renjana}

Postgraduate Student Faculty of Public Health, Universitas Indonesia, Depok, Indonesia

\section{Abstract}

Internet now becomes people's need for finding health information. This systematic review was to find out the effectiveness of the internet as a source of health information and health intervention in several countries. In developed countries, all research showed that most of the internet users tend to search health information from reliable sources and official websites. No significant result shown in improving health behavior. This systematic review found that the health workers can exploit the internet facility to approach and promote community health status.

Corresponding Author:

Anggia Ratri Renjana

anggia.rr@gmail.com

Received: 26 December 2018

Accepted: 23 February 2019

Published: 7 March 2019

Publishing services provided by Knowledge E

(c) Anggia Ratri Renjana. This article is distributed under the terms of the Creative Commons

Attribution License, which permits unrestricted use and redistribution provided that the original author and source are credited.

Selection and Peer-review under the responsibility of the $2 \mathrm{nd}$ International Meeting of Public Health 2016 Conference Committee.
Keywords: Internet intervention; health seeking behavior

\section{Introduction}

A growing trend in health care in the past decades was the increased availability of information about health, health care and specific diseases on the Internet (Ayers and Kronenfeld 2007). Currently, the internet has 513 million users worldwide. The young people continue to be one of the highest users of the Internet, often use this media to get answers to their questions, and also to search the health-related information (Sarchiapone 2013). Until 2014, Internet users in Indonesia had reached 88.1 million which were equal to $34.9 \%$ of its citizens (Indonesia APJI 2014).

Based on the National Cancer Institute's Health Information study, $68 \%$ of respondents were looking for the health-related information from the internet as their first reference, and only $16 \%$ contacted the health provider (Volkman et al. 2014). Meanwhile, a lot of information through this media on the internet were not valid. Everybody can give any information through this media (Kammerer et al. 2015), where many of that information was only based on experiences(McCaw et al. 2014; Guardiola et al. 2011).

On the other hand, the internet can give many advantages for health providers to become more flexible in reaching citizens using the alternative way besides the conventional methods. Several studies showed that the more a person found information from 
the internet, the more possible that person changed their lifestyle and health behavior (Ayers and Kronenfeld 2007; Davies et al. 2012; Maxwell 2015; Roman 2014; Milinovich 2014; Nawi and Jamaludin 2015; Plencner 2014). Another study also found that internet is an effective way to get more information besides the therapist, and the health providers, especially information related to nutrition and pregnancy (Huberty et al. 2013). Internet also constitutes a promising and cost-effective treatment alternative for a wide range of psychiatric disorders and somatic conditions (Rozental et al. 2015).

The Internet is a promising health information source and one of the facilities for health intervention if it's used in a proper way and for a correct population. Systematic Review of the previous studies needs to be done in several countries in the world to find out the effectiveness. The Internet can create and develop proper methods in promoting quality of health.

\section{Methods}

This study used Systematic Review based on PRISMA 2009. Data were obtained from online journals databases such as ProQuest and Science Direct because many studies were related to the topic. To get the latest data, the publishing year was limited from 2013 until 2016. The keywords used was internet intervention and health behavior.

\subsection{Study selection}

\section{Results}

\section{Discussion}

The studies above were held in developed countries, which had a higher living standard, high technology, and evenly economic development (Wikipedia 2015). The research in the countries of the America and Europe continents showed that Internet were more proactive and made the information from the Internet as additional information beyond the data obtained from health practitioners and tended to use the facilities of Internetbased applications available to improve the quality of their health independently. While the countries in the Asian continent, most of the internet users use the internet to find health information, only a few are willing to freely use the facilities of Internet-based applications that have been provided to improve the quality of their health. From this study, most of the respondents nowadays tend to use the internet to find out almost any information, in this case, is health-related information. Some of the respondents use the 
Keyword search identification

Title search identification

Abstract search identification

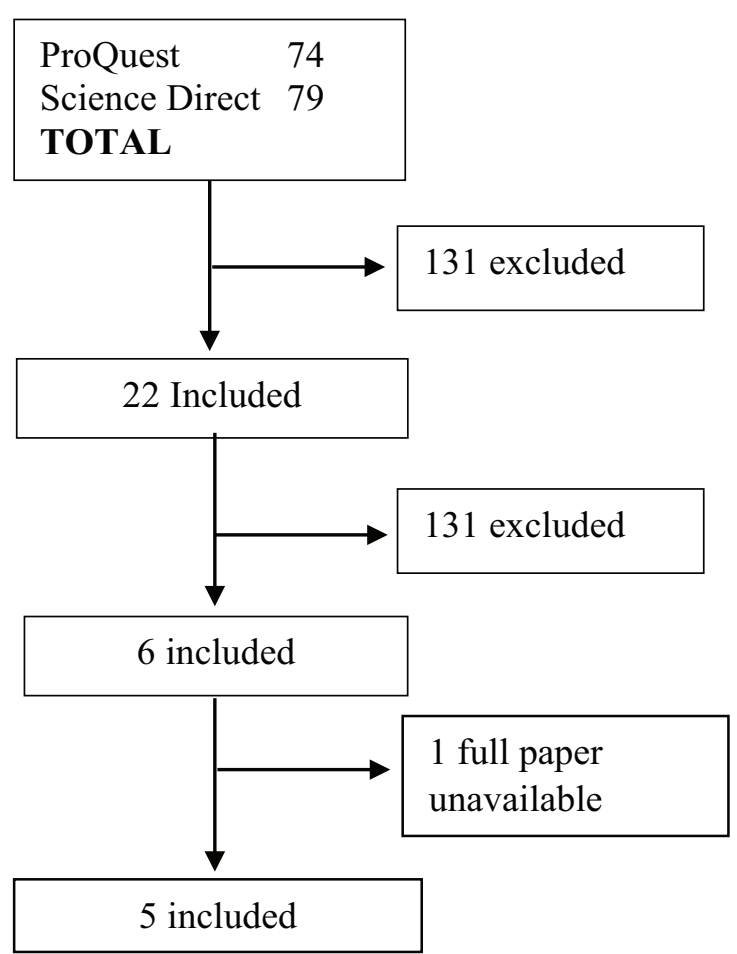

Figure 1: Selection Process.

information from the internet as an added knowledge after meeting their health provider mostly from social media, as their first reference in making their health decision, despite most of this information were not based on from scientific study result. The respondents also wish that the government and health organization provide more valid data on their official website, so they can feel safe to use the information. As we know together that finding practical and affordable ways to support the use of social media and encourage access to online health information and use of online health services could improve health literacy and self-management of health at the individual level and increase the efficiency in the provision of health services at the institutional level (Mano 2014).

\section{Limitations}

The study used different cases, methods and amount of sample, so that would not be easy to find out the relationship between each of them.

\section{Conclusions}

The Internet has become a crucial necessity in people's daily lives. As a source of health information, unfortunately, there is still a lack of valid and appropriate information available in it. This systematic review suggests that the government provide more accurate 
TABLE 1: Study Characteristic.

\begin{tabular}{|c|c|c|c|}
\hline Title & Location & Respondents & Method \\
\hline $\begin{array}{l}\text { Study } 1 . \\
\text { Describing the use of the internet for } \\
\text { health, physical activity, and nutrition } \\
\text { information in pregnant women } \\
\text { (Huberty et al. 2013) }\end{array}$ & $\begin{array}{l}\text { Midwestern } \\
\text { United States }\end{array}$ & $\begin{array}{l}293 \text { women } \\
\text { (pregnant or up to } \\
1 \text { year } \\
\text { post-partum) }\end{array}$ & $\begin{array}{l}\text { Descriptive Analysis } \\
\text { non-probabilistic } \\
\text { sample }\end{array}$ \\
\hline $\begin{array}{l}\text { Study } 2 . \\
\text { Exploring the potential for } \\
\text { Internet-based interventions for the } \\
\text { treatment of overweight and obesity } \\
\text { in college students (Schwartz and } \\
\text { Richardson 2015) }\end{array}$ & $\begin{array}{l}\text { Vancouver, } \\
\text { Canada }\end{array}$ & $\begin{array}{l}706 \text { University } \\
\text { Student }\end{array}$ & Descriptive Analysis \\
\hline $\begin{array}{l}\text { Study } 3 . \\
\text { An Internet-based health } \\
\text { management platform may } \\
\text { effectively reduce the risk factors of } \\
\text { metabolic syndrome among career } \\
\text { women (Chen et al. 2013) }\end{array}$ & Taiwan & $\begin{array}{l}66 \text { Career women } \\
\text { with metabolic } \\
\text { syndrome risk } \\
\text { factors }\end{array}$ & $\begin{array}{l}\text { Case-Control. } \\
\text { Intervention using } \\
\text { internet-based HMP } \\
\text { (Health Management } \\
\text { Platform) }\end{array}$ \\
\hline $\begin{array}{l}\text { Study } 4 . \\
\text { Social media and online health } \\
\text { services: A health empowerment } \\
\text { perspective to online health } \\
\text { information (Mano 2014) }\end{array}$ & Israel & 1406 internet user & Survey (questionnaire) \\
\hline $\begin{array}{l}\text { Study } 5 . \\
\text { Web-Based Surveillance of Public } \\
\text { Information Needs for Informing } \\
\text { Preconception Interventions } \\
\text { (D’Ambrosio 2015) }\end{array}$ & Italia & $\begin{array}{l}\text { Internet content } \\
\text { analyzed }\end{array}$ & $\begin{array}{l}\text { Analyzed the usage of } \\
\text { Google search engine } \\
\text { and identified web } \\
\text { pages containing } \\
\text { preconception care } \\
\text { recommendations. } \\
\text { Monitored how the } \\
\text { selected web pages } \\
\text { shared on social } \\
\text { networks } \\
\text { Analyzed discrepancies } \\
\text { between searched and } \\
\text { published information } \\
\text { and the sharing pattern } \\
\text { of the topics }\end{array}$ \\
\hline
\end{tabular}

information through their official website, and the health provider considers to optimally use the advantages of using internet intervention to promote a healthy lifestyle. This study may also be done in developing countries such as Indonesia.

\section{Acknowledgment}

Thank you Professor Wiku B. B. Adisasmito, Ph.D. from Public Health Faculty, University Indonesia who guided me through the process of this study. 
TABLE 2: Study Result Comparison.

\begin{tabular}{|c|c|c|c|c|}
\hline Study 1 & Study 2 & Study 3 & Study 4 & Study 5 \\
\hline $\begin{array}{l}94 \% \text { use the } \\
\text { internet to get } \\
\text { information during } \\
\text { pregnancy. } 97.8 \% \\
\text { using Yahoo / } \\
\text { Google } 57 \% \text { using } \\
\text { health institution } \\
\text { website. } \\
50 \% \text { use the } \\
\text { information } 94.4 \% \\
\text { with the } \\
\text { government } \\
\text { provide the valid } \\
\text { information from } \\
\text { official website. }\end{array}$ & $\begin{array}{l}48 \% \text { will use } \\
\text { online page for a } \\
\text { student to get } \\
\text { health } \\
\text { information. } \\
91 \% \text { use website } \\
\text { to search general } \\
\text { health } \\
\text { information. } \\
45 \% \text { watch health } \\
\text { information online } \\
\text { video } 75 \% \text { believe } \\
\text { the information } \\
\text { provides by } \\
\text { government and } \\
\text { health } \\
\text { organization. }\end{array}$ & $\begin{array}{l}\text { All respondents } \\
\text { showing behavior } \\
\text { change after } \\
\text { using this online } \\
\text { application }\end{array}$ & $\begin{array}{l}\text { Online health } \\
\text { information } \\
\text { empowers most } \\
\text { of the examined } \\
\text { individuals to use } \\
\text { online health } \\
\text { services. } \\
\text { Among all social } \\
\text { media, only those } \\
\text { that offer to } \\
\text { consult have a } \\
\text { significant effect } \\
\text { on the likelihood } \\
\text { of using online } \\
\text { health services. }\end{array}$ & $\begin{array}{l}\text { Facebook was the } \\
\text { most used social } \\
\text { network for } \\
\text { sharing. } \\
\text { Nutrition, Chronic } \\
\text { and Infectious } \\
\text { Diseases were the } \\
\text { most published } \\
\text { and searched } \\
\text { topics. } \\
\text { Medication pages } \\
\text { more frequently } \\
\text { published than } \\
\text { searched. } \\
\text { Vaccinations } \\
\text { elicited high } \\
\text { sharing although } \\
\text { web page } \\
\text { production was } \\
\text { low }\end{array}$ \\
\hline
\end{tabular}

\section{References}

[1] Ayers SL, Kronenfeld JJ. 2007. "Chronic illness and health-seeking information on the Internet."Health, 11(3):327-47.

[2] Chen Y-C, Tsao L-I, Huang C-H, Yu Y-Y, Liu I-L, Jou H-J. 2013. "An Internet-based health management platform may effectively reduce the risk factors of metabolic syndrome among career women". Elsevier, 52(2):215-21.

[3] D’Ambrosio A, Agricola E, Russo L, Gesualdo F, Pandolfi E, Bortolus R, et al. 2015. "Web-Based Surveillance of Public Information Needs for Informing Preconception Interventions."PLoS One, 10(4).

[4] Davies CA, Spence JC, Vandelanotte C, Caperchione CM, Mummery WK. 2012. "Meta-analysis of internet-delivered interventions to increase physical activity levels."International Journal of Behavioral Nutrition and Physical Activity, 9:52.

[5] Guardiola-Wanden-Berghe R, Gil-Perez JD, Sanz-Valero J, Wanden-Berghe C. 2011. "Evaluating the quality of websites relating to diet and eating disorders."Health Information and Libraries Journal, 28(4):294-301.

[6] Huberty J, Dinkel D, Beets MW, Coleman J. 2013. "Describing the use of the internet for health, physical activity, and nutrition information in pregnant women."Maternal and child health journal, 17(8):1363-72.

[7] Indonesia APJI. 2014. Profil Pengguna Internet Indonesia 2014. Pusat Kajian Komunikasi Universitas Indonesia. 
[8] Kammerer Y, Amann DG, Gerjets P. 2015. "When adults without university education search the Internet for health information: The roles of Internet-specific epistemic beliefs and a source evaluation intervention."Computers in Human Behavior, 48:297309.

[9] Mano RS. 2014. "Social media and online health services: a health empowerment perspective to online health information."Computers in Human Behavior, 39:404-12.

[10] Maxwell K. 2015. Technology as a Health Intervention and the Self-Efficacy of Men [Ph.D.]. Ann Arbor: Walden University.

[11] McCaw BA, McGlade KJ, McEInay JC. 2014. "Online health information - what the newspapers tell their readers: a systematic content analysis."BMC Public Health, 14.

[12] Milinovich GJ, Avril SMR, Clements ACA, Brownstein JS, Tong S, Hu W. 2014. "Using internet search queries for infectious disease surveillance: screening diseases for suitability."BMC Infectious Diseases, 14.

[13] Nawi AM, Jamaludin FIC. 2015. "Effect of Internet-based Intervention on Obesity among Adolescents in Kuala Lumpur: A School-based Cluster Randomised Trial."The Malaysian Journal of Medical Sciences, 22(4):47-56.

[14] Plencner A. 2014. "Critical Thinking And The Challenges Of Internet."Communication Today, 5(2):4-19.

[15] Roman T. 2014. Assessment of internet use and health information seeking by adolescents of low socioeconomic status to inform the development of a teen lifestyle social networking site [M.P.H.]. Ann Arbor: Icahn School of Medicine at Mount Sinai.

[16] Rozental A, Forsström D, Tangen JA, Carlbring P. 2015. "Experiences of undergoing Internet-based cognitive behavior therapy for procrastination: A qualitative study."Internet Interventions, 2(3):314-22.

[17] Sarchiapone M, 2013. "The Use Of Internet In Prevention. European Psychiatry; Elsevier France-Editions Scientifiques Medicales". Elsevier 23 Rue Linois, 75724 PARIS, FRANCE.

[18] Schwartz J, Richardson CG. 2015. "Exploring the potential for Internet-based interventions for the treatment of overweight and obesity in college students."Global health promotion, 22(4):20-8.

[19] Volkman JE, Luger TM, Harvey KL, Hogan TP, Shimada SL, Amante D, et al. 2014. "The National Cancer Institute's Health Information National Trends Survey [HINTS]: a national cross-sectional analysis of talking to your doctor and other healthcare providers for health information."BMC Family Practice, 15(1):1-8.

[20] www.wikipedia.org/wiki/Negara_maju. 2015. 